\title{
Transatlantica
}

Revue d'études américaines. American Studies Journal

\section{Celebrating Eudora Welty in Versailles, Paris, and} New York

\section{Pearl Amelia McHaney}

\section{Q OpenEdition}

1 Journals

\section{Electronic version}

URL: https://journals.openedition.org/transatlantica/4664

DOI: $10.4000 /$ transatlantica.4664

ISSN: $1765-2766$

\section{Publisher}

Association française d'Etudes Américaines (AFEA)

\section{Electronic reference}

Pearl Amelia McHaney, "Celebrating Eudora Welty in Versailles, Paris, and New York", Transatlantica [Online], 2 | 2009, Online since 14 January 2010, connection on 31 January 2023. URL: http:// journals.openedition.org/transatlantica/4664 ; DOI: https://doi.org/10.4000/transatlantica.4664

This text was automatically generated on 31 January 2023.

\section{(c) (i) (9)}

Creative Commons - Attribution-NonCommercial-NoDerivatives 4.0 International - CC BY-NC-ND 4.0 https://creativecommons.org/licenses/by-nc-nd/4.0/ 


\title{
Celebrating Eudora Welty in Versailles, Paris, and New York
}

\author{
Pearl Amelia McHaney
}

1 On September 10, 2009, the centennial of Eudora Welty's birth was celebrated at the Municipal Library of Versailles, 5 rue de l'Indépendance Américaine, Versailles. Coorganizers of the 2009 Southern Studies Forum Géraldine Chouard and Jacques Pothier arranged the Versailles tribute that took place in La Salle de France where John Adams, Benjamin Franklin, and John Jay negotiated the American independence from Great Britain in 1782. In this splendid atmosphere with dozens of incunabula in reach and collected editions of pre-nineteenth century authors from around the world throughout the 1762 building, the presenters and audience brought new perspectives to Welty studies.

2 Pearl McHaney, Georgia State University, spoke of Welty's parallel pursuits of writing fiction and taking photographs, illustrating Welty's success with images drawn from the published photographs and a video clip of Welty reading "Why I Live at the P.O." filmed in 1987 Yoknapatawpha Conference, at Oxford, Mississippi. Géraldine Chouard, Université Paris-Dauphine, directed attention to Welty's photographs in "The Eye of Eudora Welty" with a description of the history of Welty's visual art and an especially interesting explication of Annie Leibovitz's 1997 photographic portrait of Welty. (See Chouard's essay “Eudora Welty, vue par Annie Leibovitz : L'audace venue de l'intérieur" in Transatlantica $1: 2009)$. Isabelle Mattei, doctoral student at the Université Versailles Saint-Quentin-en- Yvelines (UVSQ), concluded this portion of the program with a presentation of her research on "Silence and Stillness in Welty," offering new ways of listening to Welty.

Madame Rose, head of the Library, spoke briefly of the historic importance of the Library and the collections available to the public for reading and research. This was followed by several readings from Welty's writings. Noel Polk read a passage from The Robber Bridegroom, giving this often overlooked 1942 novella, new expression. Tom McHaney read a selection from Welty's essay "Place in Fiction," cautioning the audience that we have too glibly quoted from this work without a clear understanding 
of the author's meaning. Pearl McHaney concluded the program with a humorous letter that Welty sent to Charles Shattuck, editor of Accent, describing Ida M'Toy's reaction to Welty's 1942 essay about her.

The Welty Centennial was also celebrated by an exhibition organized by Chouard for the entrance lobby of the library at the Université Versailles Saint-Quentin-en-Yvelines in arrangement with the Laboratory for the Study of the American Souths directed by Jacques Pothier. Drawing from her files of Welty photographs, books, posters, and supplementing with photocopies of other Welty photographs, Chouard showed the UVSQ community and the Southern Studies Forum participants meeting at UVSQ and in Paris at Université Paris-Diderot, Institut d'Anglais Charles V, September 11-13, 2009, a visual narrative of Welty's life, her writing, and her photography.

elebrations of Welty's centennial year began the previous October at the Museum of the City of New York with a photography exhibition "Eudora Welty in New York" with photos that Welty took in the 1930s. (One can read a review of the exhibition by Karen Rosenberg, "Portraits Taken by the Writer as a Young Woman (in Hard Times)," New York Times, January 9, 2009, C32.) Working with the Eudora Welty Foundation, the author's estate, and the Welty Collection of the Mississippi Department of History and Archives, curator Sean Cochran mounted an exhibition of a dozen of Welty's photographs of New York City and a reprise of forty-one of the forty-five photographs that were exhibited in 1936 at the Photographic Galleries of Lugene's Opticians, Inc., at 600 Madison Avenue, New York City, from March 31 to April 15. The majority of the photographs were the originals that Welty had printed at Standard Photo in Jackson, Mississippi, that she had matted and titled herself. A few were printed anew from the negatives, and four of the Lugene photographs named in the 1936 program remain unidentified ("20. Skirmish," "28. Near Natchez," "40. Hot Time Tonight," and "41. Groceries"). Seventeen of the Lugene photographs bear titles in Welty's penciled manuscript that differ from the Lugene titles. For example, "Teacher's day off" was labeled "Stood Up"; "Out Front" became "Spanking"; and the image of a woman looking into a store window that Welty titled "Teachers Don't Get Paid" was exhibited as "Underwear." Welty later published this image in Photographs as "Window Shopping" (available now as a limited edition from the Eudora Welty Foundation http:// www.eudorawelty.org/news.html). The exhibition program states that Welty, from "the heart of the share-cropper country" had "only the crudest of equipment" and little "experience in the darkroom." While this was true, and Welty's talent in visual arts was unheralded, we understand today, in New York, Versailles, and Paris, that she took her photographs in earnest. The Lugene's photographs that were exhibited at the Museum of the City of New York were later seen in Jackson at the Mississippi Museum of Art and the Lauren Rogers Museum of Art in Laurel, Mississippi, as programs celebrating the Eudora Welty Centennial.

6 From New York to California, Mississippi to Pennsylvania, and Versailles to Venice, the Welty Centennial programs enriched those already familiar with the American writer and photographer's work and introduced new audiences to Welty's accomplishments. 
INDEX

Subjects: Trans'Arts

\section{AUTHOR}

PEARL AMELIA MCHANEY

Georgia State University, Atlanta 